\title{
NOTES ON THE BREEDING OF TROPIDOPRIA CONICA FABR.*
}

BY G. E. SANDERS, DIVISION OF ENTOMOLOGY, OTTAWA.

In carrying on some dipterous experiments in the Division, in August, I910, many of the puparia of Eristalis tenax Linn. were found to contain the well-known parasite Iropidopria conica. About forty per cent. collected under natural conditions in August and September were found to be infested, giving on an average 35 adult parasites to each puparium. The highest number from one puparium was 46 , and the lowest $2 \mathrm{I}$.

Emergence.-This takes place through one or more round, somewhat jagged holes, about $3 \mathrm{~mm}$. in diameter, cut in the side of the puparium. The holes are cut by the adult after they bave completed their transformations. All the parasites in one puparium appear to complete their transformations at the same time, showing no indication of a partial retarded development as is so often found in similar parasites.

Mating.-About three hours after, emergence many pairs were seen together, apparently in coitu; closer examination, however, showed that

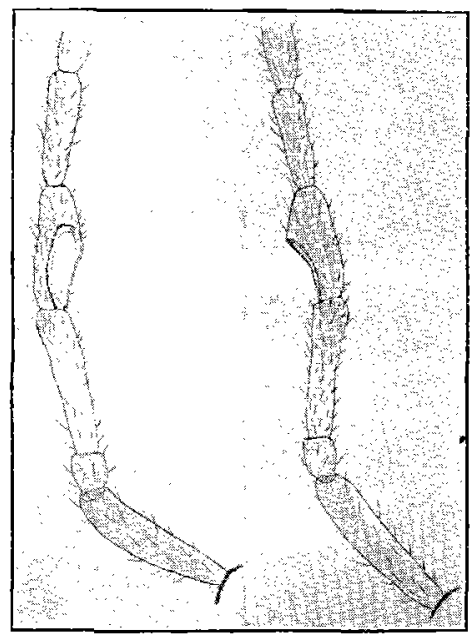

A

B

Fig, 2.--Proximal portions of antennæ of Tropidspria conica ( $\mathrm{x} 45)$. A, right antenna ; $B$, left antenna. this was not the case. The male had placed himseli firmly upon the dorsal surface of the female, and with his two front tarsi had caught hold of the antenna of the female and drawn them upwards and backwards until they lay nearly perpendicular, one on each side, close to the fore part of his thorax. The antenus of the male were thrown back so that the sense organ, or gland, situated on the fourth antennal joint, as shown in figure 2, lay directly against the antennal club of the female. This organ was being passed quickly up and down the female's antennal club, and was evidently intended to excite the female sexually; the wings of the male were raised and fluttered continuously during the process. Often this means of excitement continued for three minutes, but more often it

"Seientific Contributions from the Division of Entomology, Ottawa. Tehruary, 1911 
lasted for from thirty to forty seconds. Copulation did not follow in all cases; in several cases it did. The exciting process appears to be always preliminary to copulation.

The gland-like organ is found on the fourth antennal joint of the male in Tropidopria and many allied genera, and it appears that its sole purpose is for the exciting of the female in the manner described.

Oviposition.--This takes place in the puparium. The earliest instance was observed forty-eight hours after emergence. The ovipositor is, in all cases, inserted directly back of the respiratory "horns" in the suture forming the cap, which is forced off by the Eristalis adult in emerging. Freshly-found puparia were selected, when possible, for oviposition in preference to those in which the host was well advanced. It was observed, however, that they would deposit their eggs in old puparia when only one is exposed. Several such cases, even when the female was known to be fertilized, did not harm the host, the adult Eristalis emerging. The ovipositor appears to be inserted by a straight slow thrust; the body of the female while ovipositing is raised in a semi-circle, except for an occasional movement of the antennæ, which for the most part are extended forward and rest upon the puparium. The time from the insertion to the withdrawal of the ovipositor was taken in four cases, being 173 minutes, I 85 minutes, 96 minutes and ro r minutes respectively.

Development.-The larva is an internal feeder, developing and transforming within the soft tissues of the abdomen and thorax. In the early stages they do not retard the development of the host, as in instances where the puparia were known to be freshly formed when the eggs of the parasites were deposited in them, and when one of these was broken open fifteen days later the head, thorax and legs of the fly were found to be perfectly formed.

Length of cycle.-The two broods carried through from the egg to the adult took, in one case, 36 days, from August 7 th to September 12 th, and in the others $4 \mathrm{I}$ days, from September 7 th to October $\mathrm{I} 8$ th ; in this last case the larval and egg stages were 30 days and the pupal i 1 days. On account of the difficulty found in rearing the larve the cycle of the host could not be determined accurately. Data taken in the latter half of August and in September, when put together give the complete cycle at about 30 days-about 18 days larvæ and 12 days pupæ-in all a shorter cycle than that of the parasite. 
The adult Tropidopria is particularly long-lived; in one lot, which emerged on September 2 rst, the majority lived until October I 2 th, and a few survived until October I $_{4}$ th.

Parthenogenesis._Several pupæ were removed from one puparium and placed singly in gelatine capsules in order to secure unfertilized females. These, when they emerged, were placed on puparia which had been reared from larvæ, and were known to be free from parasites. On September I 8 th 9 adults, all males, emerged from one puparium.

Relative number of the sexes.-Under natural conditions there is a great preponderance of females. From one phial containing several puparia, $29^{8}$ parasites emerged; of these, Io I were males and 197 females. Two lots, each from one puparium, were examined, the one was found to contain 9 males and 35 females, the other 17 males and 29 females.

\section{MELITAA THEONA MENETRIES AND ITS SYNONYMY. BY. KARL R. COOLIDGE, PASADENA, CALIFORNIA.}

Melitac theona was described by Menetries in his Enumeratio corporum animalium Musei imperialis Academiæ Scientiarum Petropolitaneæ, 1855 (p. 86, and a figure, 5, on plate 2 ). Dr. Skinner has kindly sent me a copy of the original description, which reads as follows :

"444. Melitaa theona nob.--Encore une espèce de ce groupe americain de nos artemis, athalia, etc., dont on compte déjà plus d'une dixaine d'espèces. Sa taille est celie d'un petit individu de la $M$. athalia Esp., c'est-à-dire d'un pouce deux lignes d'envergure. Au premier abord, elle ressemble un peu à la $M$. editha Boisd. En dessus, les ailes sont d'un brun noirâtre, avec des bandes formées de taches jaunâtres et fauves, ainsi disposées : aux ailes supérieures, la bande la plus externe est composée de taches fauves, a l'exception de la 4 e, qui est plus grande et d'un blanc jaurâtre ; la seconde bande, qui est plus interne et plus irregulière, est formée de 7 taches d'un blanc jaunâtre; plus près de la base, on remarque plusieurs taches fauves, separées entr'elles par une tache d'un blanc jaunâtre, placée diagonalement au milieu de la cellule discoidale, puis une autre en dessous de cette cellule, plus poche de la base enfin une 3 e allongée, dans ia cellule et plus rapprochée encore de la base. Les ailes inférieures présentent une bande parallele au bord externe, composée de 8 taches fauves, ces taches sont arrondies à leur sommet et tronquées inférieurement; le disque est coupe par une autre bande paraliele de 8

Februars, 1911 